\title{
TEMPORAL VARIABILITY OF SEWAGE SLUDGE HEAVY METAL CONTENT FROM GREEK WASTEWATER TREATMENT PLANTS
}

\author{
CZASOWE ZMIANY ZAWARTOŚCI METALI CIEŻ̇KICH \\ W ŚCIEKACH Z GRECKIEJ OCZYSZCZALNI
}

\begin{abstract}
The aim of this study was to evaluate the temporal variations of selected heavy metals level in anaerobic fermented and dewatered sewage sludge. Sewage sludge samples were collected in different seasons and years from three municipal wastewater treatment plants (WWTPs) located in Northern Greece, in Kavala (Kavala and Palio localities) and Drama (Drama locality) Prefectures. An investigation of the potential of sludge utilization in agriculture was performed, based on the comparison of average total heavy metal concentrations and of chromium species (hexavalent, trivalent) concentrations with the allowed values according to the Council Directive 86/278/EEC and Greek national legislation (Joint Cabinet Decision 80568/4225/91) guidelines. In this regard, all the investigated heavy metals $(\mathrm{Cd}, \mathrm{Cr}, \mathrm{Cu}, \mathrm{Ni}, \mathrm{Pb}, \mathrm{Zn}, \mathrm{Hg}$ ) and chromium species $\mathrm{Cr}(\mathrm{VI})$ and $\mathrm{Cr}(\mathrm{III})$ have average concentrations (dry matter weight) well below the legislated thresholds for soil application, as following: $2.12 \mathrm{mg} \mathrm{kg}^{-1} \mathrm{Cd} ; 103.7 \mathrm{mg} \mathrm{kg}{ }^{-1} \mathrm{Cr} ; 136.4 \mathrm{mg} \mathrm{kg}{ }^{-1} \mathrm{Cu} ;<0.2 \mathrm{mg} \mathrm{kg} \mathrm{mg}^{-1} \mathrm{Hg} ; 29.1 \mathrm{mg} \mathrm{kg}^{-1} \mathrm{Ni}$; $62.0 \mathrm{mg} \mathrm{kg}^{-1} \mathrm{~Pb} ; 1253.2 \mathrm{mg} \mathrm{kg}^{-1} \mathrm{Zn} ; 1.56 \mathrm{mg} \mathrm{kg}^{-1} \mathrm{Cr}(\mathrm{VI})$ and $115.7 \mathrm{mg} \mathrm{kg}^{-1} \mathrm{Cr}$ (III). Values of relative standard deviation (RSD) indicate a low or moderate temporal variability for domestic-related metals $\mathrm{Zn}$ (10.3-14.7\%), $\mathrm{Pb}(27.9-44.5 \%)$ and $\mathrm{Cu}(33.5-34.2 \%)$, and high variability for the metals of mixed origin or predominantly resulted from commercial activities, such as $\mathrm{Ni}(42.4-50.7 \%), \mathrm{Cd}(44.3-85.5 \%)$ and $\mathrm{Cr}(58.2-102.0 \%)$. For some elements the seasonal occurrence pattern is the same for Kavala and Palio sludge, as following: a) $\mathrm{Cd}$ and $\mathrm{Cr}$ : spring>summer>winter; b) $\mathrm{Cu}, \mathrm{Ni}$ and $\mathrm{Pb}$ : winter>spring>summer. On average, in summer months (dry season) metal concentrations are lower than in spring and winter (wet seasons), with the exception of Zn. For Kavala and Palio the results demonstrate that the increased number of inhabitants (almost doubled) in summer time due to tourism does not influence the metal levels in sludge. Comparing the results obtained for similar spring-summerwinter sequences in 2007 and 2010/11 and for the spring season in 2007, 2008 and 2010, it can be noticed that, in general, the average heavy metal contents show an increasing tendency towards the last year. In all the measurement periods, the Palio sludge had the highest metal contents and Kavala sludge the lowest, leading to the conclusion that the WWTP operating process rather than population has a significant effect upon the heavy metal content of sludge. $\mathrm{Cr}(\mathrm{VI}) / \mathrm{Cr}$ (total) concentration ratios are higher for Kavala sludge in the majority of sampling
\end{abstract}

\footnotetext{
${ }^{1}$ Department of Petroleum and Mechanical Engineering Sciences, Eastern Macedonia and Thrace Institute of Technology, St. Lucas Street, GR 65404, Kavala, Greece, phone/fax +30 2510462270 , email: taddspanos@yahoo.com, chrchatzi@hotmail.com

${ }^{2}$ Department of Chemistry, Physics and Environment, Faculty of Sciences and Environment, Dunarea de Jos University of Galati, 47 Domneasca St., 800008 Galati, Romania, phone +40 336130 251, fax +40 236461353 ; email: aene@ugal.ro

${ }^{3}$ DEYA Dramas Municipal Water and Sewage Company, Department of Quality Control, WWTP, 2 19th May St., GR 66133, Drama, Greece, phone +30 252103 88 98, fax +30 252103 69 30, email: labdeyad@ gmail.com

*Corresponding author: aene@ugal.ro
} 
campaigns, followed by Drama and Palio sludge. The metals which present moderate to strong positive correlation have common origin, which could be a domestic-commercial mixed source.

Keywords: sewage sludge, WWTPs, heavy metals, hexavalent chromium, Kavala and Drama Prefectures, Northern Greece

\section{Introduction}

Sewage sludge is the final residual solid material that remains after the treatment of effluents in wastewater treatment plants (WWTPs). The municipal wastewater generally consists of a mixture of domestic, commercial, industrial wastewater and rainwater [1-3]. Due to the great variety of inputs and wastes in the sewer systems, wastewater contains certain undesirable components (organic, inorganic and toxic substances), and pathogenic or disease-causing micro-organisms. Sludge resulting from residential wastewater treatment processes acts as a sink of large amounts of heavy metals (cadmium, chromium, copper, mercury, nickel, lead and zinc), originated from sewage itself and sewerage pipes [4-11].

Population growth, urbanization, improvement of living conditions, and the increment of the number of inhabitants connected to WWTPs are responsible for the increase of the amount of sewage sludge produced daily (70-90 g of dry sludge/inhabitant equivalent) [10-13] and the proper disposal of sludge is a serious environmental issue worldwide $[3,14]$. Generally, the selection of the best disposal route for the sludge from a particular treatment plant requires the identification of the most secure and environmentally acceptable final destination taking into account the local, regional and/or national conditions (technical, economical, political, geographical) $[11,15,16]$. Traditional disposal alternatives which have been widely tried include landfilling, soil application, incineration and sea dumping [10-14, 17-20] and currently in Europe the most desirable use of treated sludge is in agriculture as a soil fertilizer [21]. Contrary to the European trends, in Greece sludge utilization in agriculture is very limited [3], the vast majority (> 90\%) being landfilled, while the respective mean value in EU countries is only $27 \%$ [15, 21-23]. Recent studies show an increasing trend for agricultural recycling of sludge in most EU countries, including Greece [19], and this could be a reasonable alternative, especially for plants that serve small and medium scale municipalities, for which heavy metal concentrations are anticipated to be low in the generated sludge [22].

The utilization of sewage sludge as soil fertilizer in agriculture is a viable solution for sustainable management of this waste material, as it involves the recycling of valuable non-toxic components (organic matter, nutrients, macroelements) and, in the same time, provides a low cost disposal option of the by-product [8, 10, 15-18, 24]. On one hand, this addition may represent a good alternative to prevent degradation of soils and to improve many physical, chemical and biological properties of soil [14, 25-28]. On the other hand, the high content of hazardous substances in sewage sludge, such as heavy metals (ranging from less than $1 \mathrm{mg} / \mathrm{kg}$ to over $1000 \mathrm{mg} / \mathrm{kg}$ ) [10], would increase the risk of their accumulation in the soil [17] and, subsequently, the contamination of surface and groundwater, crops and food chain, having serious consequences for animals and human health $[6,9,11,14]$. 
Directive 86/278/EEC, the so-called Sewage Sludge Directive [29], was adopted in 1986 with a view to encourage the application of sewage sludge in agriculture and to regulate its use in such a way as to prevent harmful effects on soil, vegetation, animals and human beings, containing ranges of allowed concentrations for the heavy metals $\mathrm{Cu}, \mathrm{Zn}, \mathrm{Cd}$, $\mathrm{Ni}, \mathrm{Pb}$ and $\mathrm{Hg}$ (Table 1). The revision of the Directive by the European Commission requires the further reduction in permitted concentrations of heavy metals in sludge and sludge-amended soils. European Commission published in 2000 the Working Document on Sludge, $3^{\text {rd }}$ Draft [30], which comprises microbiological criteria for the control of hygiene or stabilization processes and stricter limit values for heavy metals in sewage sludge destined for land application, including $\mathrm{Cr}$. In Greece, the management of sewage sludge is determined by the ordinances of Joint Cabinet Decision 80568/4225 of 22 March 1991 [31] on methods, specifications and requirements for the use in agriculture of the sludge originating from household and urban waste treatment (Government Gazette/641B/1991). The Ministerial Decision 80568/4225/91 adopted the same ranges of metal contents in sludge used for land application as stipulated by Directive 86/278/EEC [29], setting supplementary national thresholds for the chromium species $\mathrm{Cr}(\mathrm{III})\left(500 \mathrm{mg} \mathrm{kg}{ }^{-1}\right.$ ) and $\mathrm{Cr}(\mathrm{VI})\left(10 \mathrm{mg} \mathrm{kg}^{-1}\right)$ [23].

Table 1

Concentrations of heavy metals $(\mathrm{Cd}, \mathrm{Cr}, \mathrm{Cu}, \mathrm{Ni}, \mathrm{Pb}, \mathrm{Zn})$ and chromium species $\mathrm{Cr}(\mathrm{VI})$ and $\mathrm{Cr}(\mathrm{III})$ in the sewage sludges from Kavala (K), Drama (D) and Palio (P) WWTPs, Northern Greece, obtained in this work for the seven campaigns (in $\left[\mathrm{mg} \mathrm{kg}^{-1}\right.$ dry matter weight]) and the average values for each site

\begin{tabular}{|c|c|c|c|c|c|c|c|c|c|}
\hline \multirow{2}{*}{$\begin{array}{l}\text { Sampling } \\
\text { campaign }\end{array}$} & \multirow{2}{*}{ Sample } & \multicolumn{6}{|c|}{ Heavy metals (total concentration) } & \multicolumn{2}{|c|}{ Cr species } \\
\hline & & Cd & $\mathrm{Cr}$ & $\mathrm{Cu}$ & $\mathrm{Ni}$ & $\mathbf{P b}$ & $\mathbf{Z n}$ & $\mathrm{Cr}(\mathrm{VI})$ & Cr(III) \\
\hline \multirow{3}{*}{$\begin{array}{c}1 \\
\text { (spring 2007) }\end{array}$} & K1 & 1.2 & 18 & 101 & 11 & 55 & 895 & n.d. & n.d. \\
\hline & D1 & 1.4 & 38 & 108 & 20 & 36 & 856 & n.d. & n.d. \\
\hline & $\mathrm{P} 1$ & 1.6 & 12 & 127 & 13 & 57 & 1363 & n.d. & n.d. \\
\hline \multirow{3}{*}{$\begin{array}{c}2 \\
\text { (summer 2007) }\end{array}$} & $\mathrm{K} 2$ & 1.4 & 14 & 69 & 17 & 37 & 1061 & 0.5 & 13.5 \\
\hline & D2 & 1.8 & 24 & 53 & 14 & 43 & 1120 & 0.7 & 23.3 \\
\hline & $\mathrm{P} 2$ & 1.4 & 17 & 51 & 21 & 12 & 1840 & 0.4 & 16.6 \\
\hline \multirow{3}{*}{$\begin{array}{c}3 \\
\text { (winter 2007) }\end{array}$} & K3 & 0.9 & 65 & 106 & 34 & 68 & 998 & 0.9 & 64.1 \\
\hline & D3 & 1.8 & 180 & 134 & 62 & 74 & 1340 & 1.9 & 178.1 \\
\hline & P3 & 1.5 & 65 & 148 & 42 & 99 & 1880 & 0.8 & 64.2 \\
\hline \multirow{3}{*}{$\begin{array}{c}4 \\
\text { (spring 2008) }\end{array}$} & K4 & 0.8 & 32 & 108 & 8.8 & 52 & 1056 & 0.7 & 31.3 \\
\hline & D4 & 1.7 & 149 & 122 & 34 & 53 & 1131 & 1.3 & 147.7 \\
\hline & P4 & 1.6 & 185 & 193 & 22 & 73 & 1540 & 1.6 & 183.4 \\
\hline \multirow{3}{*}{$\begin{array}{c}5 \\
\text { (spring 2010) }\end{array}$} & K5 & 2.4 & 73 & 158 & 28 & 62 & 810 & 2.1 & 70.9 \\
\hline & D5 & 7.3 & 239 & 148 & 64 & 41 & 1080 & 3.8 & 235.2 \\
\hline & P5 & 6.1 & 355 & 184 & 45 & 94 & 1684 & 4.3 & 350.7 \\
\hline \multirow{3}{*}{$\begin{array}{c}6 \\
\text { (summer 2010) }\end{array}$} & K6 & 2.5 & 85 & 198 & 16.1 & 67 & 1095 & 1.3 & 83.7 \\
\hline & D6 & 2.2 & 227 & 165 & 33 & 49 & 1058 & 3.2 & 223.8 \\
\hline & P6 & 2.8 & 275 & 187 & 25 & 62 & 1346 & 3.6 & 271.4 \\
\hline \multirow{3}{*}{$\begin{array}{c}7 \\
\text { (winter 2011) }\end{array}$} & K7 & 1.5 & 46 & 128 & 23 & 96 & 987 & 0.31 & 45.69 \\
\hline & D7 & 1.3 & 42 & 191 & 37 & 70 & 1327 & 0.28 & 41.72 \\
\hline & P7 & 1.4 & 37 & 185 & 42 & 102 & 1850 & 0.4 & 36.6 \\
\hline \multirow{3}{*}{ Average $\pm S D$} & $\mathrm{~K}$ & $1.5 \pm 0.7$ & $48 \pm 28$ & $124 \pm 42$ & $20 \pm 9$ & $62 \pm 18$ & $986 \pm 100$ & $1.0 \pm 0.6$ & $51 \pm 26$ \\
\hline & $\mathrm{D}$ & $2.5 \pm 2.1$ & $128 \pm 93$ & $132 \pm 44$ & $38 \pm 19$ & $52 \pm 15$ & $1130 \pm 170$ & $1.9 \pm 1.4$ & $142 \pm 90$ \\
\hline & $\mathrm{P}$ & $2.3 \pm 1.7$ & $135 \pm 140$ & $154 \pm 51$ & $30 \pm 13$ & $71 \pm 32$ & $1643 \pm 230$ & $1.8 \pm 1.7$ & $154 \pm 140$ \\
\hline
\end{tabular}

n.d. - not determined; $S D$ - standard deviation 
Recent studies [32] showed that even in the case of long periods of sludge application on soil (10 years), the accumulation of toxic elements was not very high if the applied sludge contained metals at level below legislative limits, confirming that they are a warrant of conservative protection of soil quality.

Due to the heterogeneous nature of the sewage sludge produced at different municipal WWTPs and the annual/seasonal fluctuations in sludge chemical composition, an accurate knowledge of the heavy metal concentrations and their temporal variations is required when deciding on the suitability of application of sludge on agriculturally used soils [12, 14]. In this regard, literature is very scarce for Greece in the last decade; heavy metal contents of municipal WWTP sludge were reported for 18 localities from all over the country [33], Thessaloniki [4], Kalamata [22], Komotini [23] and 4 localities in Crete Island [21]. To the best of our knowledge, there is no report in Greece concerning the content of $\mathrm{Cr}(\mathrm{VI})$ and $\mathrm{Cr}$ (III) in sludge. The aim of this study was to assess the temporal variability of the total concentrations of heavy metals $\mathrm{Cd}, \mathrm{Cr}, \mathrm{Cu}, \mathrm{Hg}, \mathrm{Ni}, \mathrm{Pb}$, and $\mathrm{Zn}$, and the concentrations of chromium species $\mathrm{Cr}(\mathrm{VI})$ and $\mathrm{Cr}(\mathrm{III})$ in sewage sludges produced in three municipal WWTPs located in Kavala, Palio and Drama, Northern Greece, in seven different periods and to investigate the possibility of using the sludge for application on agricultural land in accordance with the European and Greek guidelines. The study improves and completes knowledge about Greek sludge contamination by heavy metals, provides useful information for decision makers in Greece to better manage the sewage sludge and will serve as a base in further investigations.

\section{Experimental}

\section{Sample collection and preparation}

The sewage sludges were collected from three municipal WWTPs located in Kavala and Drama Prefectures, Eastern Macedonia and Thrace region, Northern Greece, in Kavala and Drama capital cities and also from Palio, a small touristic area located $12 \mathrm{~km}$ outside of Kavala, on the North Aegean Sea coast (Fig. 1). Their populations are approximately 80,$000 ; 50,000$ and 8,000, respectively. These WWTPs receive only domestic wastewater. The production of sewage sludge at Kavala and Drama WWTPs is daily and they have primary and secondary sludge treatment, whereas in Palio station the production of sewage sludge is only 1-2 days per week, due to its reduced population. The study was performed in seven sampling campaigns in different seasons, from spring 2007 until the winter of 2010/2011, as following: 1) spring (March/April) 2007; 2) summer (August) 2007; 3) winter (December) 2007; 4) spring (April) 2008; 5) spring (April) 2010; 6) summer (August/September) 2010; 7) winter (January/February) 2011.

Each sludge sample, approximately weighting 5-8 kg, was created in the WWTP station by mixing equivalent amounts for three consecutive production days. After homogeneous mixing, a portion of each sample (about 1-1.5 kg) was dried in ambient conditions for one week in the Laboratory of Instrumental Analysis of Eastern Macedonia and Thrace Institute of Technology (TEI) Kavala, Greece, and next was placed in the oven at $90^{\circ} \mathrm{C}$ for about 12 hours until completely dried. Further, approximately half of the dried sample was grinded and then sifted in order to prepare a powder sample of about 10-15 g for the final analysis. The sludge samples were digested before instrumental analysis using microwave digestion, as described in [9]. 


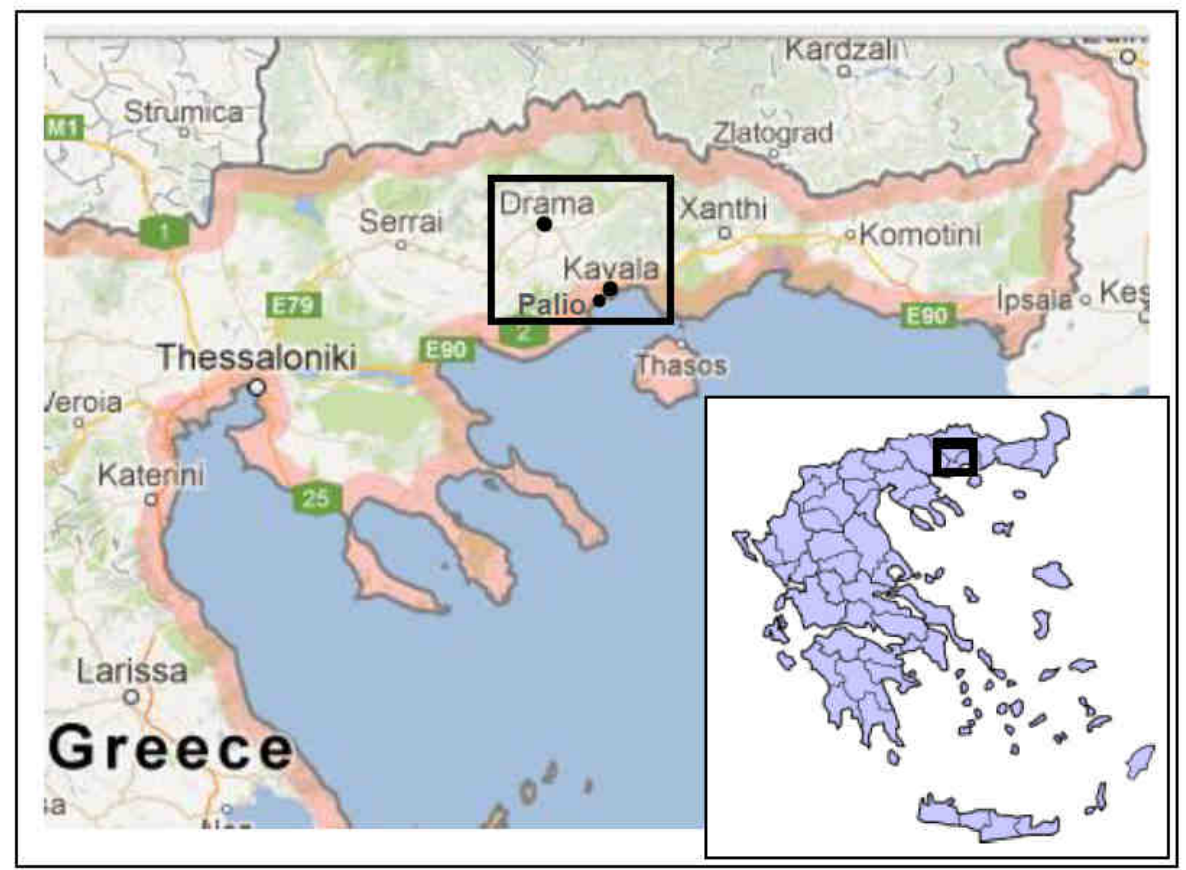

Fig. 1. Map of Greece with the locations of WWTPs in the Northern region

\section{Instrumental analyses}

Spectroscopic analytical techniques Inductively Coupled Plasma Atomic Emission Spectroscopy (ICP-AES), Cold Vapor Atomic Absorption Spectroscopy (CVAAS) and Electrothermal Atomic Absorption Spectroscopy (ETAAS) were used for sludge analysis under optimal instrumental parameters, described in detail elsewhere [9]. Briefly, ICP-AES was employed for the determination of total concentrations of the heavy metals $\mathrm{Cd}, \mathrm{Cr}, \mathrm{Cu}$, $\mathrm{Ni}, \mathrm{Pb}, \mathrm{Cd}$ and $\mathrm{Zn}$, using a JY ULTIMA 2 Jobin Yvon ICP spectrometer. The wavelengths (in $[\mathrm{nm}]$ ) used for the analysis of the metals were the following: 226.502 (Cd), 267.716 $(\mathrm{Cr}), 324.754(\mathrm{Cu}), 231.604(\mathrm{Ni}), 220.353(\mathrm{~Pb})$, and $213.856(\mathrm{Zn})$. Quantification was done using a standard calibration curve prepared with aqueous standards. Hg content was determined using CVAAS technique under optimal instrumental parameters, using a Varian AA 240 atomic absorption spectrometer equipped with a continuous flow VGA-77 vapor generation accessory. $\mathrm{Hg}$ vapor was generated from $10^{-2} \mathrm{dm}^{3}$ of sample, using $0.1 \% \mathrm{NaBH}_{4}$ as reducing agent and $0.1 \mathrm{M} \mathrm{HCl}$ as reaction medium. Quantification was done using a standard addition calibration curve prepared for each sludge sample. $\mathrm{Cr}(\mathrm{VI})$ content was determined by ETAAS technique after pretreatment, with the aid of a Zeeman 3030 Perkin-Elmer (Norwalk, CT, USA) spectrometer with a HGA-600 graphite furnace by direct sample injection $\left(20 \cdot 10^{-6} \mathrm{dm}^{3}\right)$ in pyrocoated graphite tube under optimal instrumental parameters. Only peak areas were used for quantification, as specified in the method ISO 15586: Water quality: determination of trace elements using atomic absorption spectrometry with graphite furnace, 2003. 


\section{Results and discussion}

\section{Metal levels in Greek WWTPs sludge}

The concentrations of heavy metals in the investigated sludge samples from WWTPs in the three localities Kavala (K), Drama (D) and Palio (P) are presented in Table 1, together with the average values and standard deviations (SD). Table 2 displays the legislated values in Sewage Sludge Directive 86/278/EEC [29], EU Working Document on Sludge $3^{\text {rd }}$ Draft [30] and Greek National Legislation 80568/4225/91 [31]. Mercury concentration was lower than the limit of detection of $0.2 \mathrm{mg} \mathrm{kg}^{-1}$ in all the investigated samples. $\mathrm{Cr}$ (III) concentrations given in Table 1 were calculated by the difference between total chromium and $\mathrm{Cr}(\mathrm{VI})$ concentrations.

From Table 1 it can be noticed that the heavy metal contents of the investigated sludge samples are site-specific and for most elements vary by the period of the sample collection, demonstrating that the accumulation of metals in sewage sludge produced in a WWTP which serves a specific area is an intricate process, depending upon local factors, such as population lifestyle, irregularity of raw sewage inputs from urban sources, influents' composition, as well as the treatment performance of each plant [5, 7, 9, 14, 34].

The concentrations of heavy metals in sludge form the following descending series: $\mathrm{Zn}>\mathrm{Cu}>\mathrm{Pb}>\mathrm{Cr}>\mathrm{Ni}>\mathrm{Cd}>\mathrm{Hg}$ and, overall, this distribution pattern was similar with that found by other investigators for sludge produced in various WWTPs from different countries/regions: China [16, 35, 36], Rio de Janeiro, Brasil [37], Salamanca, Spain [38], and Thessaloniki, Greece [4].

$\mathrm{Cd}$ and $\mathrm{Cr}$ (total, hexavalent and trivalent) content presents the largest variability in all the sludge samples, expressed by the relative standard deviation (RSD) (44.3-85.5\% for Cd; 58.2-102.0\% for $\mathrm{Cr}$ (total), 67.2-91.8\% for $\mathrm{Cr}(\mathrm{VI})$ and 51.0-89.2\% for $\mathrm{Cr}(\mathrm{III})$ ), as opposite of $\mathrm{Zn}$ and $\mathrm{Pb}$ contents which have the smallest variability over the entire monitoring period (10.3-14.7\% and 27.9-44.5\%, respectively). For $\mathrm{Cu}$ and $\mathrm{Ni}$ the RSD values are in a narrow range for all sites $(33.5-34.2 \% \mathrm{Cu}$ and $42.4-50.7 \%$ for $\mathrm{Ni}$ ).

Kavala sludge displays the lowest concentration variability for most metals. Similar findings for metal loading variability were reported for Spain WWTP anaerobic digested sludge by Garcia-Delgado et al [18], which obtained more reduced metal composition variability for $\mathrm{Zn}$ and $\mathrm{Pb}$, with the lowest RSD values as compared with other metals in all sludge analyzed, over the considered period of three years. On the whole, our results indicate a moderate variability compared with other reports on various WWTPs for which $\mathrm{SD}$ values are comparable or higher than the corresponding mean concentration values.

For all the investigated heavy metals and species the concentrations do not exceed the regulatory standards recommended in European [29, 30] and Greek [31] legislation, being much lower than the stipulated limits, suggesting that the sludge produced in the three WWTPs located in Northern Greece might be used in agriculture, under the assumption that the heavy metal concentrations in host soil do not limit the farmland disposal.

As compared with heavy metal levels reported in literature for sludge collected from various WWTPs, our results (Table 1) are in good agreement with those found for Kavala by other authors [25, 33], are comparable with findings for Kalamata [22], Komotini [23] and Crete [21] in Greece, for Spain [18, 28, 38], Poland [13, 27] and Brasil [34, 37], and are much lower than the values obtained for Greece at the largest WWTPs of Athens (Psyttalia and Metamorphosi) [33] and Thessaloniki [4], and also for China [35, 36] and 
Thailand [7], probably due to the fact that the WWTPs in this study only receive domestic wastewater, while industrial wastes processed in other stations usually contain higher levels of heavy metals than residential wastes [39].

Although the globalization of consumer behaviors and the standardization of construction materials tend to achieve a time-averaged heavy metal fingerprint of domestic sewage in developed cities at the urban catchment scale [6], the load of metals entering the sewer system can be modified by additional local influences, such as age of housing estates, type of piping materials and domestic appliances, quality and hardness of tap water, presence and type of commercial activities, etc. [1,39].

Table 2

Proposed concentration limits and ranges of heavy metals in European and Greek legislation (in $\left[\mathrm{mg} \mathrm{kg}^{-1}\right.$ dry matter])

\begin{tabular}{|c|c|c|c|c|c|c|c|c|c|}
\hline Guideline & Cd & $\mathbf{C r}$ & $\mathbf{C r}(\mathbf{V I})$ & $\mathbf{C r}(\mathbf{I I I})$ & $\mathbf{C u}$ & $\mathbf{H g}$ & $\mathbf{N i}$ & $\mathbf{P b}$ & $\mathbf{Z n}$ \\
\hline $\begin{array}{c}\text { EU Directive } \\
86 / 278 / \text { EEC [29] }\end{array}$ & $20-40$ & - & - & - & $1000-1750$ & $16-25$ & $300-400$ & $750-1200$ & $2500-4000$ \\
\hline EU 3 ${ }^{\text {rd }}$ Draft [30] & 10 & 1000 & - & - & 1000 & 10 & 300 & 750 & 2500 \\
\hline $\begin{array}{c}\text { Greek Legislation } \\
80568 / 4225 / 91[31]\end{array}$ & $20-40$ & $510 *$ & 10 & 500 & $1000-1750$ & $16-25$ & $300-400$ & $750-1200$ & $2500-4000$ \\
\hline
\end{tabular}

$* \mathrm{Cr}($ total $)=(\mathrm{Cr}(\mathrm{III})+\mathrm{Cr}(\mathrm{VI})],-$ not specified

\section{Temporal variations of sludge metal contents}

Figure 2 shows the seasonal (Fig. 2a), and annual (Fig. 2b) variations of metal concentrations for all investigated samples. The heavy metal concentration variations in spring months in each year are presented in Figure 3.

Despite the high variability of sludge metal concentrations, which is a general feature of this type of waste worldwide, some conclusions could be drawn based on the data presented in Table 1, Figures 2 and 3.

For some elements the seasonal occurrence pattern is the same for $\mathrm{K}$ and $\mathrm{P}$ sludge (Figs. 2a and 3), as following: a) $\mathrm{Cd}$ and $\mathrm{Cr}$ : spring>summer>winter; b) $\mathrm{Cu}, \mathrm{Ni}$ and $\mathrm{Pb}$ : winter>spring >summer. On average, in summer months (dry season) metal concentrations are lower than in spring and winter (wet seasons), with the exception of $\mathrm{Zn}$, and for $\mathrm{K}$ and $\mathrm{P}$ the results demonstrate that the increased number of inhabitants (almost doubled) in summer time due to tourism does not influence the metal levels in sludge. These findings are contrarily to those obtained for Greece by Andreadakis et al [33], which found $\mathrm{Zn}$ concentrations in Kavala sludge more than 2-fold lower in summer 1999 than in winter 2000, and by Angelidis and Aloupi [25] which reported increased concentrations of domestic effluent-related metals $\mathrm{Cu}, \mathrm{Pb}$ and $\mathrm{Zn}$ in sewage sludge from Sparta WWTP during the summer period, attributed to the population growth of the city during this period because of tourism. For Kavala WWTP sludge, Angelidis and Aloupi [25] recorded no differences in all the metal $(\mathrm{Cd}, \mathrm{Cr}, \mathrm{Cu}, \mathrm{Ni}, \mathrm{Pb}$ and $\mathrm{Zn}$ ) contents between dry (October 1993) and wet (January 1994) seasons, due to the fact that the city of Kavala was not subjected to important fluctuations of its population in those months. Moreover, Garcia Delgado et al [18] reported for Salamanca (Spain) sludge that all investigated metals $(\mathrm{Cd}, \mathrm{Cr}, \mathrm{Cu}, \mathrm{Ni}, \mathrm{Pb}$ and $\mathrm{Zn}$ ) displayed higher concentrations during the summer, compared to winter months. 
a)
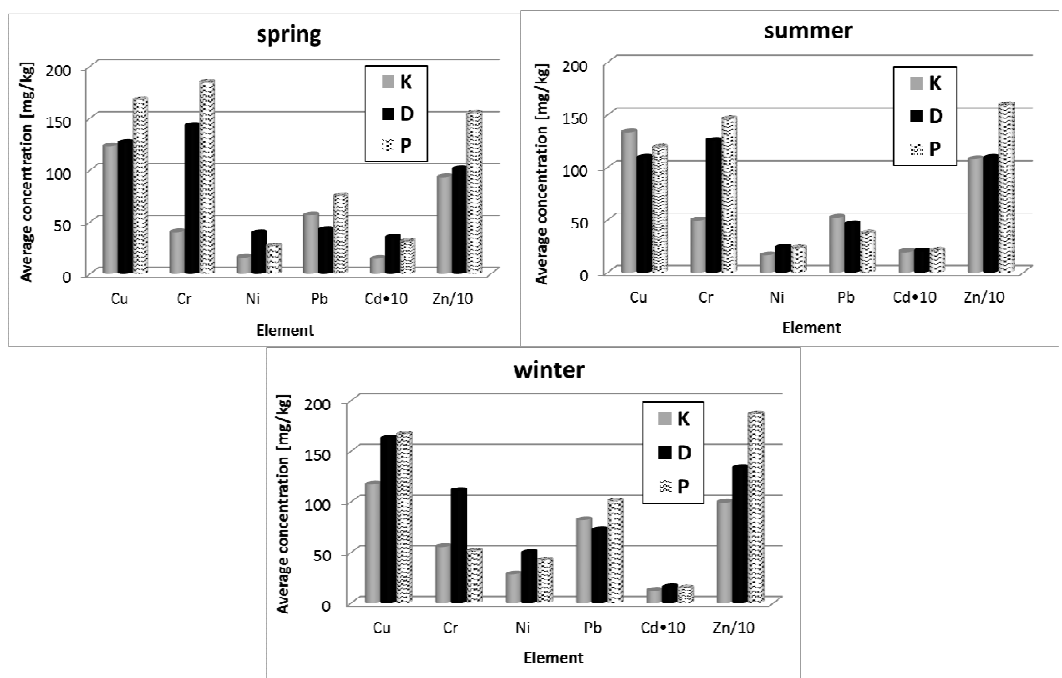

b)
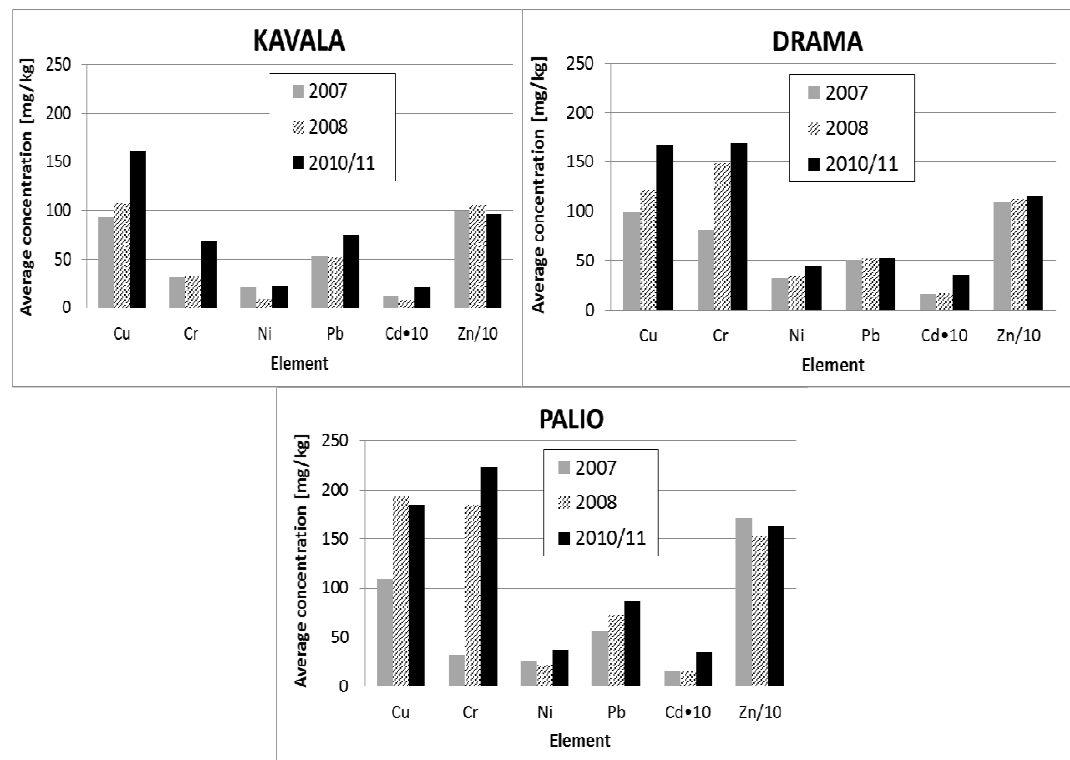

Fig. 2. Temporal variation of average heavy metal concentrations in investigated sewage sludges obtained in this work for Kavala (K), Drama (D) and Palio (P) WWTPs: a) seasonal pattern, b) annual pattern

Pearson correlation coefficients ( $r$ ) shown in Table 3 indicate high positive correlation between the elements $\mathrm{Cd}-\mathrm{Cr}$ (total and $\mathrm{VI}$ ), $\mathrm{Pb}-\mathrm{Cu}$ and $\mathrm{Pb}-\mathrm{Ni}$ for $\mathrm{P}$ sludge; $\mathrm{Cu}-\mathrm{Cd}$ and $\mathrm{Cu}-\mathrm{Cr}$ (total) for $\mathrm{K}$; $\mathrm{Zn}-\mathrm{Pb}$, Ni-Cr(total) and $\mathrm{Cd}-\mathrm{Cr}(\mathrm{VI})$ for $\mathrm{D}$ sludge and moderate positive correlation for $\mathrm{Cd}-\mathrm{Cr}$ (total and $\mathrm{VI}$ ), $\mathrm{Ni}-\mathrm{Cr}$ (total) and $\mathrm{Cu}-\mathrm{Cr}(\mathrm{VI})$ for $\mathrm{K}$ sludge; $\mathrm{Ni}-\mathrm{Zn}$ and $\mathrm{Cu}-\mathrm{Cr}$ (total and VI) for $\mathrm{P}$ and $\mathrm{Ni}-\mathrm{Cu}, \mathrm{Ni}-\mathrm{Cd}, \mathrm{Ni}-\mathrm{Cr}(\mathrm{VI})$ and $\mathrm{Cd}-\mathrm{Cr}$ (total) for $\mathrm{D}$ sludge. 

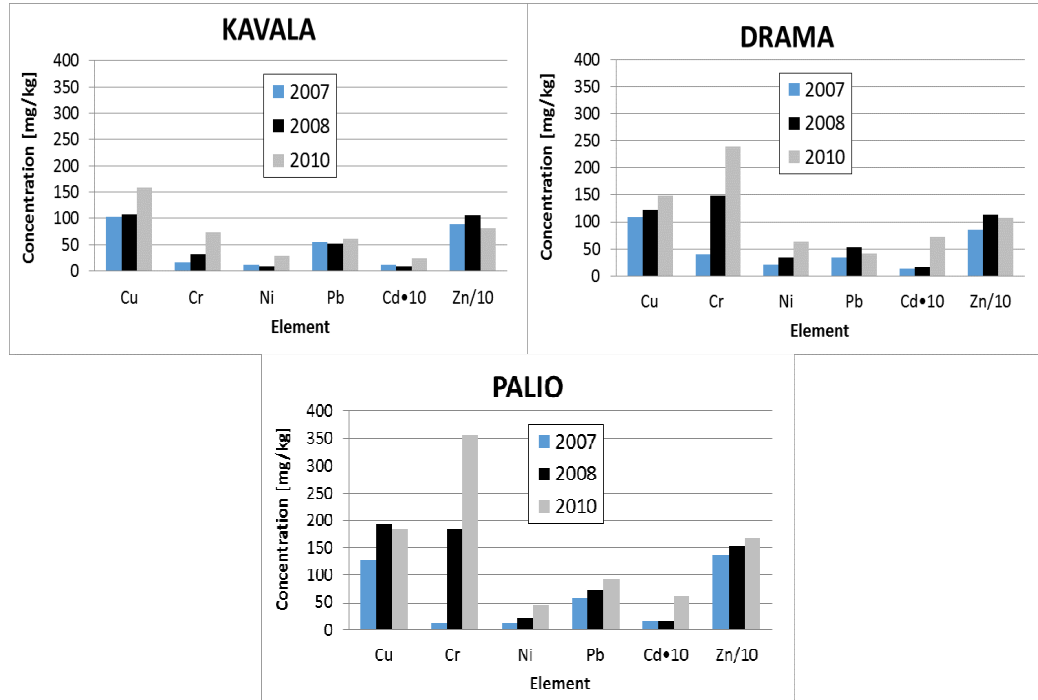

Fig. 3. Annual variation of heavy metal concentrations in spring months obtained in this work in sewage sludges from Kavala, Drama and Palio WWTPs

Table 3

Correlation matrix for metal concentration values in the investigated Greek sewage sludge collected in seven campaigns in the period 2007-2011

\begin{tabular}{|c|c|c|c|c|c|c|c|c|}
\hline & WWTP & $\mathbf{C u}$ & Cr(total) & $\operatorname{Cr}(\mathrm{VI})$ & $\mathbf{N i}$ & $\mathbf{P b}$ & Cd & $\mathbf{Z n}$ \\
\hline \multirow{3}{*}{$\mathrm{Cu}$} & $\mathrm{K}$ & 1.000 & & & & & & \\
\hline & $\mathrm{D}$ & 1.000 & & & & & & \\
\hline & $P$ & 1.000 & & & & & & \\
\hline \multirow{3}{*}{$\mathrm{Cr}$ (total) } & $\mathrm{K}$ & 0.855 & & & & & & \\
\hline & $\mathrm{D}$ & 0.412 & & & & & & \\
\hline & $P$ & 0.614 & & & & & & \\
\hline \multirow{3}{*}{$\mathrm{Cr}(\mathrm{VI})$} & $\mathrm{K}$ & 0.624 & 0.700 & & & & & \\
\hline & $\mathrm{D}$ & 0.241 & 0.930 & & & & & \\
\hline & $\mathrm{P}$ & 0.499 & 0.982 & & & & & \\
\hline \multirow{3}{*}{$\mathrm{Ni}$} & K & 0.115 & 0.552 & 0.313 & & & & \\
\hline & $\mathrm{D}$ & 0.510 & 0.728 & 0.573 & & & & \\
\hline & $P$ & 0.425 & 0.314 & 0.136 & & & & \\
\hline \multirow{3}{*}{$\mathrm{Pb}$} & $\mathrm{K}$ & 0.449 & 0.469 & -0.106 & 0.414 & & & \\
\hline & $\mathrm{D}$ & 0.490 & 0.072 & -0.445 & 0.447 & & & \\
\hline & $\mathrm{P}$ & 0.788 & 0.283 & 0.177 & 0.759 & & & \\
\hline \multirow{3}{*}{$\mathrm{Cd}$} & $\mathrm{K}$ & 0.806 & 0.644 & 0.689 & 0.151 & 0.171 & & \\
\hline & $\mathrm{D}$ & 0.144 & 0.606 & 0.757 & 0.610 & -0.343 & & \\
\hline & $P$ & 0.359 & 0.844 & 0.875 & 0.450 & 0.283 & & \\
\hline \multirow{3}{*}{$\mathrm{Zn}$} & $\mathrm{K}$ & -0.093 & -0.129 & -0.657 & -0.420 & -0.152 & -0.251 & 1.000 \\
\hline & $\mathrm{D}$ & 0.357 & 0.099 & -0.559 & 0.475 & 0.920 & -0.124 & 1.000 \\
\hline & $P$ & -0.322 & -0.393 & -0.681 & 0.612 & 0.183 & -0.145 & 1.000 \\
\hline
\end{tabular}

Coefficients marked in boldface are statistically significant at $p<0.05$

There is a moderate negative correlation between $\mathrm{Zn}$ and $\mathrm{Cr}(\mathrm{VI})$ in all the samples. We hypothesize that the metals which present moderate to strong positive correlation have 
common origin, which could be a domestic-commercial mixed source. The information existing in the literature identified domestic inputs (tap water, food, detergents, personal care products, toilet, dissolution of internal parts of domestic appliances, plumbing) as the largest overall sources of $\mathrm{Cu}, \mathrm{Zn}$ and $\mathrm{Pb}$ entering the urban WWTP system $[1,5,6,39]$. Estimates of Ni loadings from domestic sources are highly variable and this contribution may be similar to, or greater than, the commercial input [1]. $\mathrm{Cr}$ and $\mathrm{Cd}$ derive mostly from commercial activities in an urban agglomeration $[1,25]$ and their source could be related to business effluents [4], from small-size companies and micro-industrial units, such as laundry cleaning, food processing, leather manufacturers, restaurants, medical/dental practices, goldsmiths, painting and photographic shops, car washing and repair, garages, etc. [1]. However, the contribution of domestic sources (faeces, food products, household cleaning agents, washing powders, body care products, etc.) to the loading of $\mathrm{Cd}$ and $\mathrm{Cr}$ in wastewater, and consequently in sludge, could not be neglected $[1,6,10]$. Cr(VI) could originate in urban sludge from tap water (groundwater contaminated from industrial processes), drinking water distribution system from corrosion inhibitors used in water pipes and products containing chromates and dichromates [40, 41].

There is a very strong correlation between $\mathrm{Cr}$ (total) and $\mathrm{Cr}(\mathrm{VI})$ in $\mathrm{D}$ and $\mathrm{P}$ sludge ( $r=0.930$ and 0.982 , respectively), and a high correlation in KA sludge $(r=0.700)$. Although $\mathrm{Cr}(\mathrm{VI})$ concentrations are the highest in $\mathrm{P}$ sludge (Table 1), the $\mathrm{Cr}(\mathrm{VI}) / \mathrm{Cr}($ total) concentration ratios presented in Figure 4 are higher for $K$ sludge in the majority of sampling campaigns, followed by $\mathrm{D}$ and $\mathrm{P}$ sludge. Exception is made for winter time campaigns nos. 3 (2007) and 7 (2010/11) - when a different ratio pattern is observed, with a maximum for $\mathrm{P}$ station in the last year (2010/11). The highest ratios were found in the second campaign (summer 2007) for all three stations.

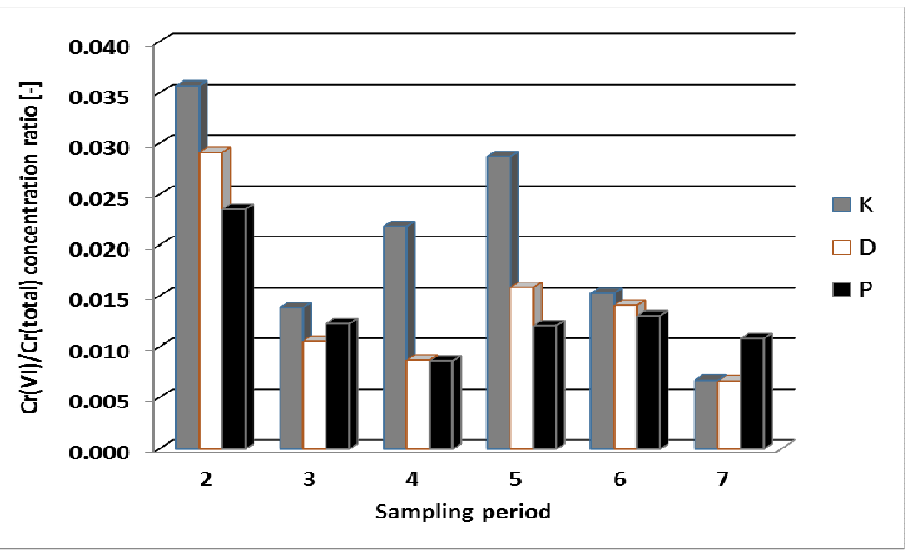

Fig. 4. $\mathrm{Cr}(\mathrm{VI}) / \mathrm{Cr}$ (total) concentration ratio in the studied sludge samples from Kavala (K), Drama (D) and Palio (P) WWTPs for different sampling periods: 2 - August 2007; 3 - December 2007; 4 - April 2008; 5 - April 2010; 6 - August/September 2010; 7 - January/February 2011

We noted that in all the measurement periods the Palio $(\mathrm{P})$ sludge had the highest metal contents and Kavala (K) sludge the lowest. There is no relation with sampling date/season or number of residents, since the city of Palio has the lowest population of the three 
localities and Kavala the largest number of inhabitants, and this demonstrates that the WWTP operating process rather than population has a significant effect upon the metal content of sludge, as found by [7] for Bangkok (Thailand) WWTPs. A longer operational condition and storage time, as is the case of P WWTP, may increase the metal contents due to the decomposition of biodegradable organic matter by microorganisms [7]. Occurrence of most heavy metals in lower concentrations in Kavala sludge compared to sludge from other Greek WWTPs is in accordance with the findings [33] for Kavala WWTP among 18 studied WWTPs in Greece.

Comparing the similar period sequences spring-summer-winter in 2007 and 2010/11, it can be noticed from Figure $2 \mathrm{a}$ that the mean metal contents show a tendency of increase in the last year, with the exception of $\mathrm{Zn}$ content in $\mathrm{K}$ and $\mathrm{P}$ sludge, which had a slight decrease in 2010/11 (Fig. 2b). The same increasing trend is observed when comparing the different sites for spring months over the period considered of three years (2007, 2008 and 2010) (Table 1, Fig. 3), with a low temporal variability (RSD) for domestic-related metals $\mathrm{Zn}$ (10.5-14.3\%), $\mathrm{Pb}$ (9.1-24.9\%) and $\mathrm{Cu}$ (16.1-25.4\%), and high RSD values for metals of mixed origin or predominantly resulted from commercial activities, Ni (57.2-65.9\%), $\mathrm{Cd}(56.8-95.9 \%)$ and $\mathrm{Cr}(69.7-93.2 \%)$.

\section{Conclusions}

The reported data corresponding to the 4-year monitoring give useful information regarding the variability of heavy metal concentrations in sludge from three different Greek sewage treatment plants, in order to assess the suitability for sludge application on farmland. The periodic study on the heavy metal content of sludge conducted in this work do not reveal high toxicity levels. Despite the demonstrated temporal variability, the concentrations of selected heavy metals ( $\mathrm{Cd}, \mathrm{Cr}, \mathrm{Cu}, \mathrm{Hg}, \mathrm{Ni}, \mathrm{Pb}, \mathrm{Zn}$ ) and $\mathrm{Cr}$ species $\mathrm{Cr}(\mathrm{VI})$ and $\mathrm{Cr}(\mathrm{III})$ determined in all the investigated sludges are very low and, according to the Sewage Sludge Directive and Greek Ministerial Decision, the sewage sludge meets the requirements for using in agricultural land, from the point of view of the heavy metal content.

It is important to note that the determination of heavy metals in the sewage sludge produced in Drama and Palio WWTPs was made for the first time in this work and therefore, besides the results for Kavala WWTP, is an important statistical element for the quality of the produced sludge in Greece and future comparisons.

Although the practice of using the sludge in agriculture is applied to a lesser extent in Greece compared to E.U. countries, it will promote and contribute to environmental protection and will reduce the use of chemical fertilizers. Due to the fact that the region of Northern Greece is characterized by elevated heavy metal concentrations in soil and groundwater, the monitoring of heavy metal amounts in the soil in the application area is required before the sludge disposal, besides the continuous monitoring of sludge.

\section{Acknowledgements}

The authors wish to thank the staff of the chemical laboratories of TEI Kavala, Greece, where the instrumental analyses were performed. Special thanks are extended to Municipal Authorities of Kavala, Drama and Palio for providing the sewage sludge samples. Prof. dr. habil. Antoaneta Ene acknowledges the financial support of Bilateral agreement 
through Programme Erasmus+ (2014-2016) between "Dunarea de Jos” University of Galati, Romania, and TEI Kavala, Greece.

\section{References}

[1] European Communities. Pollutants in urban waste water and sewage sludge. Final Report. Luxembourg: Office for Official Publications of the European Communities; 2001. http://ec.europa.eu/ environment/archives/waste/sludge/pdf/sludge_pollutants_xsum.pdf.

[2] Eriksson E, Christensen N, Schmidt JE, Ledin A. Potential priority pollutants in sewage sludge. Desalination. 2008;226:371-388. DOI: 10.1016/j.desal.2007.03.019.

[3] Samolada MC, Zabaniotou AA. Comparative assessment of municipal sewage sludge incineration, gasification and pyrolysis for a sustainable sludge-to-energy management in Greece. Waste Manage. 2014;34(2):411-420. DOI: 10.1016/j.wasman.2013.11.003.

[4] Karvelas M, Katsoyiannis A, Samara C. Occurrence and fate of heavy metals in the wastewater treatment process. Chemosphere. 2003;53(10):1201-1210. DOI: 10.2166/wst.2008.230.

[5] Ustün GE. Occurrence and removal of metals in urban wastewater treatment plants. J Hazard Mater. 2009;172(2-3):833-838. DOI: 10.1016/j.jhazmat.2009.07.073.

[6] Houhou J, Lartiges BS, Montarges-Pelletier E, Sieliechi J, Ghanbaja J, Kohler A. Sources, nature, and fate of heavy metal-bearing particles in the sewer system. Sci Total Environ. 2009;407(23):6052-6062. DOI: 10.1016/j.scitotenv.2009.08.019.

[7] Chanpiwat P, Sthiannopkao S, Kim KW. Metal content variation in wastewater and biosludge from Bangkok's central wastewater treatment plants. Microchem J. 2010;95:326-332. DOI: 10.1016/j.microc.2010.01.013.

[8] Grübel K, Machnicka A, Nowicka E, Wacławek S. Mesophilic-thermophilic fermentation process of waste activated sludge after hybrid disintegration. Ecol Chem Eng S. 2014;21(1):125-136. DOI: 10.2478/eces2014-0011.

[9] Spanos T, Ene A, Karadjova IB. Assessment of toxic elements $\mathrm{Cu}, \mathrm{Cr}, \mathrm{Ni}, \mathrm{Pb}, \mathrm{Cd}, \mathrm{Hg}, \mathrm{Zn}, \mathrm{As}$ and hexavalent chromium in sewage sludge from municipal wastewater treatment plants by combined spectroscopic techniques. Romanian J Phys. 2015;60(1-2):237-245. http://www.nipne.ro/rjp/ 2015_60_1-2/0237_0245.pdf.

[10] Van de Velden M, Dewil R, Baeyens J, Josson L, Lanssens P. The distribution of heavy metals during fluidized bed combustion of sludge (FBSC). J Hazard Mater. 2008;151(1):96-102. DOI: 10.1016/j.jhazmat.2007.05.056.

[11] Fytili D, Zabaniotou A. Utilization of sewage sludge in EU application of old and new methods - A review. Renew Sustain Energ Rev. 2008;12:116-140. DOI: 10.1016/j.rser.2006.05.014.

[12] Barrera-Diaz C, Martínez-Barrera G, Gencel O, Bernal-Martínez LA, Brostow W. Processed wastewater sludge for improvement of mechanical properties of concretes. J Hazard Mater. 2011;192(1):108-115. DOI: 10.1016/j.jhazmat.2011.04.103.

[13] Werle S, Dudziak M. Influence of wastewater treatment and the method of sludge disposal on the gasification process. Ecol Chem Eng S. 2014;21(2):255-268. DOI: 10.2478/eces-2014-0020.

[14] Singh RP, Agrawal M. Potential benefits and risks of land application of sewage sludge. Waste Manage. 2008;28(2):347-358. DOI: 10.1016/j.wasman.2006.12.010.

[15] Karagiannidis A, Samaras P, Kasampalis T, Perkoulidis, G, Ziogas P, Zorpas A. Evaluation of sewage sludge production and utilization in Greece in the frame of integrated energy recovery. Desalin Water Treat. 2011;33(1-3):185-193. DOI: 10.5004/dwt.2011.2613.

[16] Chen H, Yan SH, Ye ZL, Meng HJ, Zhu YG. Utilization of urban sewage sludge: Chinese perspectives. Environ Sci Pollut Res. 2012;19(5):1454-1463. DOI: 10.1007/s11356-012-0760-0.

[17] Goi D, Tubaro F, Dolcetti G. Analysis of metals and EOX in sludge from municipal wastewater treatment plants: A case study. Waste Manage. 2006;26(2):167-175. DOI: 10.1016/j.wasman.2005.03.006.

[18] García-Delgado M, Rodríguez-Cruz MS, Lorenzo LF, Arienzo M, Sánchez-Martín MJ. Seasonal and time variability of heavy metal content and of its chemical forms in sewage sludges from different wastewater treatment plants. Sci Total Environ. 2007;382(1):82-92. DOI: 10.1016/j.scitotenv.2007.04.009

[19] Kelessidis A, Stasinakis AS. Comparative study of the methods used for treatment and final disposal of sewage sludge in European countries. Waste Manage. 2012;32(6):1186-1195. DOI: 10.1016/j.wasman.2012.01.012. 
[20] Latosinka J, Gawdzik J. The impact of combustion technology of sewage sludge on mobility of heavy metals in sewage sludge ash. Ecol Chem Eng S. 2014;21(3):465-475. DOI: 10.2478/eces-2014-0034.

[21] Kalderis D, Aivalioti M, Gidarakos E. Options for sustainable sewage sludge management in small wastewater treatment plants on islands: The case of Crete. Desalination. 2010;260(1-3):211-217. DOI: 10.1016/j.desal.2010.04.030.

[22] Lyberatos G, Klimantos P, Vassilakis I, Kornaros M. On the impact of land application of secondary sludge. Water Air Soil Poll Focus. 2004;4(4-5):349-357. DOI: 10.1023/B:WAFO.0000044810.38944.ff.

[23] Stefanakis AI, Tsihrintzis VA. Heavy metal fate in pilot-scale sludge drying reed beds under various design and operation conditions. J Hazard Mater. 2012;213-214:393-405. DOI: 10.1016/j.jhazmat.2012.02.016.

[24] Cai QY, Mo CH, Wu QT, Zeng QY, Katsoyiannis A. Concentration and speciation of heavy metals in six different sewage sludge-composts. J Hazard Mater. 2007;147(3):1063-1072. DOI: 10.1016/j.jhazmat.2007.01.142.

[25] Angelidis MO, Aloupi M. Assessment of sewage sludge quality in Greece. Toxicol Environ Chem. 1999;68(1-2):133-139. DOI: 10.1080/02772249909358651.

[26] Gondek K. Quantity and quality of organic matter in soil after application of various organic materials. Ecol Chem Eng S. 2014;21(3):477-485. DOI: 10.2478/eces-2014-0035.

[27] Gawdzik A, Gawdzik B, Gawdzik A, Gawdzik A. New indices determining heavy metals migration in a sewage sludge. Ecol Chem Eng S. 2015;22(4):637-644. DOI: 10.1515/eces-2015-0038.

[28] Roig N, Sierra J, Nadal M, Marti E, Navalon Madrigal P, Schuhmacher M, Domingo JL. Relationship between pollutant content and ecotoxicity of sewage sludges from Spanish wastewater treatment plants. Sci Total Environ. 2012;425:99-109. DOI: 10.1016/j.scitotenv.2012.03.018.

[29] European Council Directive 86/278/EEC of 12 June 1986 (The Sewage Sludge Directive) on the protection of the environment, and in particular of the soil, when sewage sludge is used in agriculture. Off $\mathrm{J}$ Eur Communities L181, 4 July 1986,6-12. http://eur-lex.europa.eu/legal-content/EN/TXT/HTML/ ?uri=URISERV:128088\&from $=$ EN.

[30] European Commission. Working document on sludge, $3^{\text {rd }}$ Draft. Brussels, 27 April 2000.

[31] Ministerial Decision, Greek legislation 80568/4225/91 of 22 March 1991 on methods, specifications and requirements for the use in agriculture of the sludge originating from household and urban waste treatment, harmonized from European Council Directive 86/278/EEC, 1991.

[32] Contin M, Goi D, De Nobili M. Land application of aerobic sewage sludge does not impair methane oxidation rates of soils. Sci Total Environ. 2012;441:10-8. DOI: 10.1016/j.scitotenv.2012.09.052.

[33] Andreadakis AD, Mamais D, Gavalaki E, Kampylafka S. Sludge utilisation in agriculture: possibilities and prospects in Greece. Water Sci Technol. 2002;46(10):231-238. http://wst.iwaponline.com/content/ $46 / 10 / 231$.

[34] da Silva Oliveira A, Bocio A, Trevilato TMB, Takayanagui AMM, Domingo JL, Segura-Muñoz SI. Heavy metals in untreated/treated urban effluent and sludge from a biological wastewater treatment plant. Environ Sci Pollut Res. 2007;14(7):483-489. DOI: 10.1065/espr2006.10.355.

[35] Wang $\mathrm{C}, \mathrm{Hu} \mathrm{X}$, Chen ML, Wu YH. Total concentrations and fractions of $\mathrm{Cd}, \mathrm{Cr}, \mathrm{Pb}, \mathrm{Cu}, \mathrm{Ni}$ and $\mathrm{Zn}$ in sewage sludge from municipal and industrial wastewater treatment plants. J Hazard Mater. 2005;119(1-3):245-249. DOI: 10.1016/j.jhazmat.2004.11.023.

[36] Dai J, Xu M, Chen J, Yang X, Ke Z. PCDD/F, PAH and heavy metals in the sewage sludge from six wastewater treatment plants in Beijing, China. Chemosphere. 2007;66(2):353-361. DOI: 10.1016/j.chemosphere.2006.04.072.

[37] de Souza Pereira M, Kuch B. Heavy metals, PCDD/F and PCB in sewage sludge samples from two wastewater treatment facilities in Rio de Janeiro State, Brazil. Chemosphere. 2005;60(7):844-853. DOI: 10.1016/j.chemosphere.2005.01.079.

[38] Walter I, Martínez F, Cala V. Heavy metal speciation and phytotoxic effects of three representative sewage sludges for agricultural uses. Environ Pollut. 2006;139(3):507-514. DOI: 10.1016/j.envpol.2005.05.020.

[39] Rule KL, Comber SD, Ross D, Thornton A, Makropoulos CK, Rautiu R. Diffuse sources of heavy metals entering an urban wastewater catchment. Chemosphere. 2006;63(1):64-72. DOI: 10.1016/j.chemosphere.2005.07.052.

[40] Vaiopoulou E, Gikas P. Effects of chromium on activated sludge and on the performance of wastewater treatment plants: A review. Water Res. 2012;46(3):549-570. DOI: 10.1016/j.watres.2011.11.024.

[41] Economou-Eliopoulos M, Antivachi D, Vasilatos C, Megremi I. Evaluation of the Cr(VI) and other toxic element contamination and their potential sources: The case of the Thiva basin (Greece). Geosci Frontiers. 2012;3(4):523-539. DOI: 10.1016/j.gsf.2011.11.010. 